\title{
REFUGEES, THE RULE OF LAW AND EXECUTIVE POWER: A(NOTHER) CASE OF THE CONJUROR'S RABBIT?
}

\section{Dr Peter Billings, Principal Lecturer in Law, Human Rights Unit, University of the West of England*}

"The whole topic of Crown prerogatives is veiled in a mist of doctrinal and historical obscurity, and the existence or scope of many prerogatives is not always easily determined."

\section{INTRODUCTION}

In Ruddock $\mathrm{v}$ Vadarlis $^{2}$ the Federal Court of Australia was asked to determine several complex legal and constitutional questions. One question addressed by the court was the legality of the Australian Government's decision to deport $^{3}$ putative refugees from its territorial waters around Christmas Island before any consideration of their asylum claims. ${ }^{4}$ Specifically, the court had to examine, inter alia, important questions about executive power ${ }^{5}$ and its relationship to statute. The majority of the court determined that the executive had, and retained, the power to deport asylum seekers sailing aboard a Norwegian container ship (the MV Tampa) towards Christmas island. The court decided that the executive power was not abrogated or abridged by a statutory regime (Migration Act 1958) ${ }^{6}$ that provided for the comprehensive regulation of entry into Australia by nonnationals.

* The author gratefully acknowledges Barry Berkan, Richard Clements, Professor Gabrielle Ganz, Jane Kay, and Dr Ben Pontin for their helpful comments. In particular, I am indebted to Associate Professor Susan Kneebone for her observations on an earlier draft. The usual disclaimer applies.

1 Edeson, "The Prerogative of the Crown to Delimit Britain's Maritime Boundary" [1973] PL 364.

2 (2001) 66 A.L.D. 25. The High Court refused to entertain an appeal against the decision of the Federal Court (Vadarlis v MIMA M93/2001 <www.austlii.edu.au /au/other/hca/transcripts/2001/M93/3.html> (accessed 3 July 2003). See Head, "The High Court and the Tampa Refugees" (2002) 11(1) Griffith LR 23.

3 The terms deportation and expulsion are synonymous; expulsion is part of the vocabulary of international law, deportation is used in the domestic context. Since the Tampa refugees were in Australian territory and this analysis is concerned with prerogative powers I shall employ the former term. By contrast, exclusion encapsulates situations of non-admission at the border. Although the Australian government did not wish to admit the Tampa refugees they were within Australian territory.

4 The case is, therefore, distinguishable from the policy of interdiction on the high seas (in relation to Haitian asylum seekers) which was upheld by the US Supreme Court in Sale v Haitian Centers Council 113 Sup Ct 2549.

5 See infra note 15 and associated text for details.

6 As amended (see Border Protection Legislation Amendment Act 1999 in the context of this case). 
The case is located in the interstices of domestic law, human rights treaties, customary international law and sovereign rights. This analysis is primarily concerned with domestic (public) law although international law is also highly relevant to the discussion. The decision in Ruddock $\mathrm{v}$ Vadarlis raises questions of constitutional importance ${ }^{7}$ about the precise legal relationship between statute and prerogative powers, the balance of power between executive and Parliament, and the rule of law. First, how far did the unwritten powers of the Crown extend, historically, and did the residual prerogative power claimed actually exist any longer? Secondly, where statute and prerogative powers appear to regulate the same area, which source can be relied upon to validate the exercise of public power? Bound up with both of these questions is the issue of whether 'state necessity' is a relevant, or determining factor in such judicial analyses.

The first problem, namely, whether the power to authorise the asylum seekers' deportation (and detention to that end) actually existed, is the type of task the courts have undertaken for several centuries. ${ }^{8}$ The second problem, of theoretical and practical importance, is also not new to judges, scholars and law students; fêted cases include De Keyser's Royal Hotel ${ }^{9}$ and ex parte Fire Brigades Union, ${ }^{10}$ and Markesinis provided a rigorous analysis thirty years ago. ${ }^{11}$ The present author's concern is to critically address those aspects of the decision in Ruddock that analyse the difficult question of precisely when a prerogative power is abrogated or abridged by statute - by implication. This question is far from "trite". ${ }^{12}$ Indeed, as Markesinis noted, where the prerogative is not explicitly referred to in the statute, in terms of it being either abolished, restricted, preserved (but subject to regulation in the $\mathrm{Act}^{13}$ ) or wholly unaffected, the relationship remains "strangely abstruse". ${ }^{14}$

7 For a critical examination of the implications of the case for domestic refugee law and practice in Australia, see Mathew, "Australian Refugee Protection In The Wake Of The Tampa" [2002] 96 AJIL 661. For an analysis of Australia's obligations under international law and customary international law, see Bostock, "The International Legal Obligations owed to the Asylum Seekers on the MV Tampa" (2002) 14(2/3) IJRL 279. For an alternative view see Blay, "The case of MV Tampa: state and refugee rights collide at sea" (2002) $76 A L J 12$. For an analysis of the refugee law, maritime law and domestic law implications see Willheim, "MV Tampa: The Australian Response" (2003) 15(2) IJRL 159.

8 In fulfilling this task the courts have attracted criticism for some of their decisions. For example, see Edeson, supra $\mathrm{n} 1$ and Bradley, "Police Powers and the Prerogative" [1988] PL 298.

9 Attorney-General v De Keyser's Royal Hotel Ltd [1920] A.C. 508.

${ }^{10} R \mathrm{v}$ Secretary of State for the Home Department, ex parte Fire Brigades Union [1995] 2 A.C. 513. See also, $R$ (Mahmood and another) v Royal Pharmaceutical Society of Great Britain [2002] 1 W.L.R. 879.

11 Markesinis, "The Royal Prerogative Revisited" [1973] 32(2) CLJ 287.

12 Per Lord Bridge in Co Williams Construction Ltd v Blackman [1995] 1 W.L.R. 102 , at 108.

13 For example, the Immigration Act 1971 s 33(5) provides: "This Act shall not be taken to supercede or impair any power exercisable by Her Majesty in relation to aliens by virtue of Her Prerogative."

14 Markesinis, supra n 11, at 299. 


\section{The Facts}

At the behest of the Australian government, the MV Tampa, a Norwegian registered container ship, rescued 433 asylum seekers from a sinking fishing boat in the Indian Ocean on 26 August 2001. When the captain of the vessel changed course and headed for Christmas Island with the rescuees aboard the Australian government refused to permit the MV Tampa from entering Australian waters and asked her to head toward Indonesia. However, the $M V$ Tampa entered Australian waters on 29 August, because the ship's captain was concerned about the potential loss of life given the condition of his passengers and the risk of travelling across open waters to Indonesia. In response the Australian Defence Force interdicted the vessel and boarded her. The asylum seekers were transferred to HMAS Manoora around 3 September. Legal proceedings began on behalf of the asylum seekers on 31 August. Mr Vadarlis (a solicitor) and the Victorian Council for Civil Liberties sought a restraining injunction, on the basis that, inter alia, the executive had no lawful authority to expel the rescuees from Australian waters.

During the course of the final hearing of the applications, which commenced on 2 September, the parties agreed that the asylum seekers aboard the HMAS Manoora could be taken to Nauru and New Zealand for initial processing. These arrangements were subsequently, referred to as 'The Pacific Solution'.

\section{The Statutory Framework}

Executive power is contained in Commonwealth of Australia Constitution Act 1900 section 61.15 This section "confers on the Commonwealth all the prerogative powers of the Crown except those that are necessarily exercisable by the States under the allocation of responsibilities made by the Constitution and those denied by the Constitution itself." 16 Thus, prerogative powers are the historical antecedents of the 'executive' power provided for in section 61 of the Commonwealth of Australia Constitution Act 1900. ${ }^{17}$ The long title of the Migration Act 1958 provides: "an Act relating to the entry into, and presence in, Australia of aliens, and the departure or deportation from Australia of aliens and certain other persons." Section 4(1) reads: ". . . the object of this Act is to regulate, in the national interest, the coming into, and presence in, Australia of non-citizens." Section 6 established that the Migration Act was to apply to those persons in Australia but outside the migration zone (as the Tampa refugees were). Other key provisions were sections $189(2), 245 \mathrm{~F}(9)$ and 256. Section 189(2) provided for the detention of unlawful non-citizens who were outside the migration zone. Section $245 \mathrm{~F}(9)^{18}$ expanded Australia's ability to board, search and detain ships, and detain those aboard at sea. Section 256 was relevant because it provided that

15 S 61 provides: "The executive power of the Commonwealth is vested in the Queen, and is exercisable by the Governor-General as the Queen's representative, and extends to the execution and maintenance of this Constitution, and of the laws of the Commonwealth."

16 Davis v Commonwealth (1988) 16 C.L.R. 79, at 93.

17 See generally, Barton v Commonwealth (1974) 131 C.L.R. 477, at 498 and Davis v Commonwealth (1988) 166 C.L.R. 79, at 93-93, 107-108.

18 Amendment added via the Border Control Protection Act 1999. 
those in detention under the Migration Act could have access to certain facilities at their request, such as legal advice and visa application forms. ${ }^{19}$

Australia's protection obligations under the Convention Relating to the Status of Refugees 1951 (Geneva Convention) and its Protocol 1967, ${ }^{20}$ are referred to in section 36(2) of the Migration Act. ${ }^{21}$ There is a right to seek asylum under international law, but no correlative duty to admit asylum seekers incumbent upon states. ${ }^{22}$ However, Article 33 (the non-refoulement norm) of the Geneva Convention precludes states from returning asylum seekers to a place where their life or freedom would be threatened; by reason of their race, religion, nationality, membership of a particular social group or political opinion. Furthermore, Article 31 provides that asylum seekers are not to be penalised for arriving illegally. It applies where they have come directly from the place where they were persecuted, present themselves without delay to the authorities and show good cause for their illegal entry or presence.

\section{The Judgments}

On 11 September, in the Federal Court, North J, held that there was no relevant executive power that could authorise the deportation of the asylum seekers and ordered their return to Australia for processing. Two days later the full Federal Court heard an appeal by the government. ${ }^{23}$ The majority (Black C.J. dissenting) overturned the determination of North J., deciding that the steps taken in relation to the asylum seekers to prevent them lodging asylum claims in Australia were within the scope of executive power, and therefore lawful.

\section{The Majority}

First, French J. opined that there was no place "for any doctrine that a law made on a particular subject matter is presumed to displace or regulate the operation of the executive power." ${ }^{24}$ It was a matter of construction. As a prelude to this conclusion, the judge drew a distinction between prerogative

19 The Australian government did not invoke these provisions to detain the $M V$ Tampa and those aboard precisely because it did not want the refugees to avail themselves of the procedural guarantees contained within the Migration Act.

201951 Convention Relating to the Status of Refugees 189 U.N.T.S. 150; and United Nations Protocol 1967 Protocol Relating to the Status of Refugees 606 U.N.T.S. 267.

21 "(2) A criterion for a protection visa is that the applicant is a non-citizen in Australia to whom Australia has protection obligations under the Refugee Convention as amended by the Refugees Protocol." The refugee definition was implemented in domestic law by the Migration Amendment Act (No 2) 1980.

22 Art 14(1) of the 1948 Universal Declaration of Human Rights provides that: "Everyone has the right to seek and enjoy in other countries asylum from persecution." U.N.G.A. resolution 217 A(III).

23 The hearing dates are potentially significant, coinciding with the terrorist attacks in the USA. Mathew notes: "One can only speculate about the different light in which the division between legislative and executive powers may have appeared to particular judges depending on whether the court sat before or after September 11." (Mathew, supra $\mathrm{n} 7$, at 662).

24 (2001) 66 A.L.D. 25, 70 [183]. 
and executive powers, notwithstanding their common historical origins. The executive power of the Commonwealth under section 61 could not be treated as a species of the royal prerogative. Section 61 was conferred as part of a negotiated federal compact expressed in a written Constitution distributing power between the three arms of government, he observed. ${ }^{25}$ This seems a rather novel and unconvincing attempt to make a conceptual distinction between prerogative and executive powers. ${ }^{26}$ This cannot mean that the Executive can claim, or the courts recognise and enforce, new or broader powers based on the prerogative. This would undermine the fundamental principle that: "[I]t is 350 years and a civil war too late for the Queen's courts to broaden the prerogative." 27 Moreover, in Australian Communist Party v Commonwealth, Williams J. considered that: "the executive power of the Commonwealth at the date of the Constitution presumably included such of the then existing prerogative powers of the King in England as were applicable to a body politic of limited powers." 28

The inference here is that before Australia became a sovereign state only some prerogative powers could be exercised by the Governor General (on the advice of the Executive) or the States' Governors. Consequently, after independence, although Australia was no longer a limited political body, only those prerogative powers that were in existence at the date the Constitution, could be utilised, not more. Thus, French J. must have meant that executive power under section 61 has a life of its own as an indigenous concept distinct from prerogative powers.

In construing the operation of statute upon executive power, French J. reasoned that close scrutiny of the statute was merited where its purported effect was to displace an executive power "intimately connected to Australia's status as a sovereign nation-state". ${ }^{29}$ The greater the significance of the particular executive power the less likely it was that parliament would extinguish it, absent express wording or inescapable implication. ${ }^{30}$ The importance of the executive power to national sovereignty was a recurring theme in French J's judgment. ${ }^{31}$

Secondly, in reliance on precedents over a century old, ${ }^{32}$ French J. underlined the right of a state to exclude or expel aliens under international law. ${ }^{33} \mathrm{He}$ distinguished those precedents from two other expulsion cases involving Chinese immigrants ${ }^{34}$ because the executive power claimed in those two cases was contrary to a statute, under which there was at least implied

25 Ibid.

26 There is of course a difference between personal prerogative powers of the Monarch (or their delegate, such as the Governor General in Australia) to dissolve the legislature for example, and executive powers such as signing a treaty.

27 BBC v Johns [1965] Ch 32, at 79.

28 (1951) 83 C.L.R. 1, at 230.

29 (2001) 66 A.L.D. 25, 71 [185].

30 Ibid.

31 Infra note 38 and associated text.

32 Re Adam [1837] 1 Moo P.C., 12 E.R. 889; Musgrove v Toy [1891] A.C. 272.

33 The relevance of the supreme power inherent in states to refuse entry to nonnationals is explored subsequently, see infra at note 49 and associated text.

34 Ex parte Lo Pak (1888) 9 N.S.W.R. 221; Ex parte Leong Kum (1888) 9 N.S.W.R. 254. 
permission to enter the colony. ${ }^{35}$ Moreover, the judge attached importance to the fact that these (apparently contradictory) cases were determined when Australia was a colony and not a sovereign state. He contended: "The scope of the executive power conferred by section 61 of the Constitution is to be measured by reference to Australia's status as a sovereign nation." ${ }^{36}$ It is one thing to acknowledge that the scope of executive power was limited when Australia was a colony. However, quite another to intimate that subsequently, the content of executive power is wider than the content of the Crown's prerogative powers extant at the time of the Constitution from which executive power ostensibly derived. In short, it cannot be correct that the court permitted the Australian Government to exercise executive powers that are 'wider' than the prerogative powers of the Crown from which they derive conceptually. It is also relevant, though not determinative, that those powers had not been exercised for at least a century. ${ }^{37}$ Common law prerogative powers provided neither a concrete historical basis, nor contemporary legal basis, for the claimed power.

Nevertheless, French J. opined that the Constitution provided sufficiently wide powers to authorise the executive action under review:

"The power to determine who may come into Australia is so central to its sovereignty that it is not to be supposed that the government of the nation would lack the power conferred upon it directly by the Constitution, the ability to prevent people not part of the Australian community, from entering." 38

Thus, the judge stressed the importance of those executive powers intimately connected to Australia's status as an independent, sovereign, nation-state. Lane refers to 'sheer' executive acts, deriving from "the character and status of the Commonwealth as a national government" and cites as an example "the protection of the constitution and constitutional government [. . .] against terrorist activities." 39 However, it is difficult to conceive of the threat to constitutional government in this case, thereby justifying the use of such "will-o'-the-wisp" 40 powers against putative refugees. Furthermore, by observing that section 61 "like the power to make laws with respect to defence, [it] will vary according to circumstances", ${ }^{41}$ the judge's dicta has a familiar ring to it. In $R$ v Secretary of State for the Home Department, ex parte Northumbria Police Authority, surprisingly, a case not referred to in any of the judgments, the Court of Appeal recognised the existence of a prerogative of keeping the peace of the realm. In the, infamous, words of Nourse L.J:

(2001) 66 A.L.D. 25, 73 [190].

36 Ibid at 73 [191].

37 Indeed, French J. acknowledged the comments of Barton J. in Robtelmes v Brenan (1906) 4 C.L.R. 395, at 414; the Encyclopedia of the Laws of England, vol 5 at p 298 provided that although the Crown could use its prerogative to expel aliens it had not attempted to do so since the Glorious Revolution (ibid at 74 [194]).

38 Ibid at 173 [194].

39 Lane, Lane's Commentary on the Australian Constitution (LBC Information Services 1997) at 130-131, 438-439.

40 Ibid at 131.

41 (2001) 66 A.L.D. 25, 74 [197]. 
"There is no historical or other basis for denying to the war prerogative a sister prerogative of keeping the peace within the realm. . . [ $\mathrm{t}$ ]he scarcity of references in the books to the prerogative of keeping the peace within the realm does not disprove that it exists. Rather, it may point to an unspoken assumption that it does." 42

This decision has been roundly criticised, by Bradley, who argued that the judges, by recognising the existence in law of a hitherto uncertain power of the Crown, actually increased uncertainty in the law; specifically, concerning the relationship between the power and legislation and its capacity to authorise new forms of executive action. Referring to Entick v Carrington, he reasoned that

"the thrust of Entick is that the English courts should take a hard look at assertions of prerogative power and, even where a claim of state necessity is argued, refrain from providing new precedents accepting such claims." 43

French J. decided that the executive power claimed by the government was implicit in section 61 and its scope was wide enough to encompass the interdiction of the Tampa. ${ }^{44}$ Furthermore, given its centrality to notions of state sovereignty, the courts should construe legislation covering the same area narrowly. Therefore, he concluded that the Migration Act did not abrogate the executive power. The statute did not contain express words to that effect, nor did it, as a matter of construction, evince a clear and unambiguous intention to do so. ${ }^{45}$

Beaumont J. agreed with the reasoning of French J., and added some further reasons of his own:

"In my opinion, the primary judge should have inquired whether at common law [. . . ] there was a legal right in the occupants to enter Australia. If his Honour had asked this question, it would, in accordance with the settled course of authority, have been answered in the negative." ${ }^{\prime 4}$

Beaumont J. surveyed relevant authorities beginning with Musgrove v Toy, ${ }^{47}$ where the Privy Council held that, apart from statute, an alien had no legal

42 [1988] 1 All E.R. 556, at 575, and per Purchas L.J at 566. Infamous, because it contrasts sharply with Lord Camden's words in Entick v Carrington (1765) 19 St. Tr. 1030, 1067, 1073.

43 Bradley, supra $\mathrm{n} 8$, at 301.

44 Contrast this with Lim v Minister for Immigration, Local Government and Ethnic Affairs (1992) 176 C.L.R. 1, where the High Court made it clear that administrative detention of asylum seekers arriving by boat required specific statutory authorisation: "any officer of the Commonwealth Executive who purports to authorize or enforce the detention in custody of such an alien without judicial mandate will be acting lawfully only to the extent that his or her conduct is justified by valid statutory provision." (at 19).

45 (2001) 66 A.L.D. 25, 75 [201].

46 (2001) 66 ALD 25, 52 [111].

47 [1891] A.C. 272. Approved in Johnstone v Pedlar [1921] 2 A.C. 262 and $R$ v Carter ex parte Kisch (1934) 52 C.L.R. 221. 
right enforceable by action to enter Victoria. ${ }^{48}$ He continued with reference to Attorney-General (Canada) v Cain, where Lord Atkinson, following Musgrove, observed, "[o]ne of the rights possessed by the supreme power in every State is the right to refuse to permit an alien to enter that State." ${ }^{49}$ After citing several similar authorities ${ }^{50}$ he allowed the appeal by simply concluding that aliens had no right to enter Australia. Thornberry has criticised the decision in Musgrove v Toy owing to the absence of any authority advanced in support of the proposition that an alien has no right of entry, and the lack of any principled discussion. ${ }^{51}$ Moreover, in respect of the decision in Attorney-General (Canada) v Cain, he opined that "the prerogative of expulsion was produced by the Privy Council rather as a conjuror produces a rabbit. It was simply assumed that the Crown possessed the right." $" 52$

Moreover, the cases relied on by Beaumont and French JJ refer to the power possessed by states under international law. Yet as French J. recognised, the, "way in which the right to expel or to refuse entry is exercised, and whether by legislative or executive means, may vary according to the constitutional mechanisms of particular states." 53 Thus, the manner in which this international law principle was given further effect should have entailed an examination of municipal law. Consideration of the relationship between the Migration Act and executive power was a vital undertaking. Accordingly, with respect, Beaumont J's approach to the inquiry was wrong. There is a critical difference between the supreme power in every state to regulate the entry of aliens under international law and prerogative powers at common law. The vexing question of whether there was, and remained, a common law prerogative right to deport non-nationals was the correct inquiry for the court to pursue. But "the Crown can have no prerogative by the law of nations". ${ }^{54}$ What may be permissible under international law ${ }^{55}$ has no bearing on the existence of any constitutional power.

It is paradoxical that both judges were content to employ this international law maxim whilst affording Australia's international law obligations to refugees a cursory inspection. French J. concluded that "nothing done by the

48 Ibid at 282, obiter dicta of the Lord Chancellor, in terms reminiscent of the 'act of State' doctrine.

49 [1906] A.C. 542, at 546. It was not clear whether the references to the supreme power of each state to refuse to admit a non-national were intended to be references to the prerogative at all.

50 Ah Yin v Christie (1907) 4 C.L.R. 1428, 13 A.L.R. 372; Udny v Udny (1869) L.R. 1 Sc. \& Div. 441.

51 Thornberry, "Dr Soblen and the Alien Law of the UK" (1963) 12 ICLQ 414, at 424.

52 Ibid, at 425 .

53 (2001) 66 A.L.D. 25, 72 [186].

54 Craies, "The Right of Aliens to Enter British Territory" (1890) 6 LQR 27, 36.

55 There appears to be a consensus among scholars and judiciary that a state may exclude non-nationals under international law. However, see Nafziger, "The General Admission of Aliens Under International Law" [1983] 77 AJIL 804, for an illuminating critique of this proposition. The author demonstrates how the early authorities, cited in modern cases such as Ruddock, to support the exclusionary proposition, were based on a selective reading of the work of Vattel, Pufendorf and others. 
executive on the face of it amounts to a breach of Australia's obligations in respect of non-refoulement under the Refugee Convention." 56 Meanwhile, Beaumont $\mathrm{J}$, in a postscript, urged any extra-judicial assessment of executive policy in this case to be undertaken bearing in mind the obligations incumbent on states under Article 33 of the Refugee Convention. Namely, in his view, that there was no obligation under international law to resettle those rescued in a state's territory. ${ }^{57}$ This perfunctory examination of the importance and relevance of international norms has been criticised by another member of the judiciary and laid bare by academics..$^{58}$

\section{The Dissentient}

Black C.J., expressed doubt as to the continuing existence of the claimed prerogative. He pointed to judicial and extra-judicial observations that supported the proposition that prerogative powers could fall into disuse and, consequently, be considered extinguished because they had become incompatible with modern constitutional jurisprudence. ${ }^{59}$ His historical survey of the jurisprudence and academic commentary led to the conclusion that, "by the end of the nineteenth century, in English jurisprudence, the power to exclude aliens in times of peace was not considered to be part of the prerogative." ${ }^{60}$ It was "at best, doubtful that the asserted prerogative power continues to exist at common law: [. . .] its existence is entirely uncertain, and there are no previous modern instances of its exercise." ${ }^{61}$ Hence, although it may have been propitious for the Australian government to resuscitate an ancient prerogative power, by doing so they were breathing new life into a prerogative that had long since expired. ${ }^{62}$

Haycraft's historical analysis led him to conclude that it appeared that the Crown did possess a prerogative right to exclude and expel foreigners. ${ }^{63}$ However, there was a strong parallel current of opinion in the opposite direction. In terms that ring true over a century later, he opined:

"[I]t is hardly conceivable that a government would desire to use for such a purpose powers which have fallen out of common use, until the whole question has been discussed in Parliament, and it is known what exercise of powers, if any, Parliament considers necessary for the protection of our common interests." ${ }^{\circ 4}$

56 Ibid, at 76 [203]. See Blay, supra $\mathrm{n}$ 7, at 17 for a concurring opinion. Contrast this with the analysis by Mathew, supra $\mathrm{n}$ 7, at 665-667.

57 (2001) 66 A.L.D. 25, 54 [126].

58 See Nicholson C.J. whose lecture was quoted in "Current Issues" (2002) 76 ALJ 405; and Mathew, supra $\mathrm{n}$ 7, at 665-667.

59 (2001) 66 A.L.D. 25, 31 [20].

60 Per Black C.J., at 32 [26].

61 Ibid, at 33 [29].

62 A view supported by several academic authorities, see Craies supra $n 54$, at 29 ; Thornberry supra n 51 at 424; and Goodwin-Gill, "The Limits of the Power of Expulsion in Public International Law" (1976) 55 BYIL 106-7.

63 Haycraft, "Alien Legislation and the Prerogative of the Crown" (1897) 13 LQR 165.

64 Ibid at 185. 
Yet, "a vanishing prerogative is a strange creature, for there is no generally accepted principle of law that a prerogative may be lost by deseutude." ${ }^{65}$ However, although a common law rule, once clearly established does not become extinct merely by disuse, it remains capable of recrudescence in propitious circumstances only when it would not be grossly anomalous and anachronistic (author's emphasis). ${ }^{66}$ Evidently the common law rule permitting the Australian Government to deport asylum seekers was not clearly established (as Beaumont J. contended) and reviving it in 2001 was grossly anomalous and anachronistic.

Proceeding on the basis that the existence of a common law power to exclude aliens in peacetime was, at best, 'doubtful', Black C.J. examined the scope of section 61 to determine if it was wider than its prerogative antecedent:

"It would be a very strange circumstance if the at best doubtful and historically long-unused power to exclude or expel should emerge in a strong modern form from s 61 of the Constitution by virtue of general conceptions of the "national interest" This is all the more so when according to English constitutional theory new prerogative powers cannot be created" 67

But assuming there was such a prerogative power, was it abrogated by the Migration Act 1958?

Black C.J. was content to rely upon De Keyser's and Laker Airways Ltd v Department of Trade, ${ }^{68}$ to support the following proposition - that "where the prerogative is relied on as an alternative source of power to action under a statute, the prerogative will be held to be displaced when the statute covers the subject matter." 69 He then examined the question of the clarity with which an intention to displace a prerogative or executive power needs to be expressed:

"It can readily be conceded that if a power is well-used, well established and important to the functioning of executive government, a very clear manifestation of an intention to abrogate will be required, But, similarly, where an asserted power is at best doubtful, and where, if it exists at all, it does so in a field that has been the concern of parliament for a very long time, a less stringent view of the intention necessary to abrogate such a power is appropriate. Another such indication may be where the parliament has entered a field in which Australia has assumed treaty obligations and has acted to give effect to those obligations in that field and where the asserted prerogative or executive power might be capable of exercise in

65 De Smith and Brazier, Constitutional and Administrative Law (Penguin, 1998), at 136. In Re F (Mental Patient: Sterilisation) [1990] 2 A.C. 1 at 26, Neill L.J. stated, "It seems to me that it would require clear statutory words to remove from the Crown a prerogative power which has vested in the Crown since at least 1325."

66 McKendrick v Sinclair [1972] S.L.T. 110, at 116 per Simon L.J..

67 (2001) 66 A.L.D. 25, at 33 [30].

68 [1920] AC 508; [1977] 1 Q.B. 643

69 (2001) 66 A.L.D. 25, at 35 [37]. 
a manner not conformable with the parliament's provision for the satisfaction of those obligations." 70

In support of his view that any residual discretion was abridged, the judge referred to the long title of the Migration Act 1958 and section 4(1). The latter provides that ". . . the object of this Act is to regulate, in the national interest, the coming into, and presence in, Australia of non-citizens." 71 Moreover, the Act refers to Australia's protection obligations under the 1951 Geneva Convention. ${ }^{72}$ Black C.J. seized on the reference to the "national interest" in section 4(1) as "suggestive of a recognition by the parliament of its unquestioned power to determine comprehensively what the national interest shall be in this respect." 73 Further, the "national interest" includes recognition of obligations under the Geneva Convention. In conjunction with the provisions in the Border Protection Legislation Amendment Act 1999, the Migration Act provided a comprehensive regime for the control of Australia's borders and the patrol of the territorial waters. That statutory regime covered circumstances such as those affecting the asylum seekers at the relevant time. The judge was plainly of the view that the power claimed by the Executive was excluded, by implication, because the legislation evinced a very clear intention to cover the field in question exhaustively. ${ }^{74}$ The uncertain nature of the power asserted on behalf of the executive fortified this view. The regime could have applied to the rescued people had the government "not taken a view" that it did not wish to apply the Act. ${ }^{75}$

The judge's analysis of precisely when a statute displaces a prerogative or executive power is worthy of closer inspection. First, he agreed with French J. that the importance of the power to the functioning of executive government was a relevant factor when determining the relationship between statute and prerogative. However, he added that the power must also be well-used and well established. Second, he considered it relevant that the field had been the concern of Parliament for a very long time. Third, he opined that weight should be attached to Australia's obligations under international law, although they were not incorporated into Australian law. The use of international law to inform the development of common law visà-vis the relationship between statute and prerogative (executive) powers merits further evaluation.

The status of the 1951 Geneva Convention Relating to the Status of Refugees and its 1967 Protocol in domestic law is "tenuous". ${ }^{76}$ The Migration Act

70 Ibid, at 36 [40].

71 The wide scope of the Act was confirmed by the Immigration and Multicultural Affairs Minister, Philip Ruddock, during the second reading (House of Representatives, Parliamentary Debates, Hansard 22 September 1999, at 10147) (cited by Black C.J. at 40 [62]). Furthermore, there is no provision analogous to s 33(5) Immigration Act 1971 that expressly preserves the residue of discretionary authority.

72 In much the same way that the UK's protection obligations arising under the 1951 Convention are alluded to in s 11996 Asylum and Immigration Act.

73 (2001) 66 A.L.D. 25, 37 [44].

74 See de Smith, and Brazier, supra $n$ 65, at 139-40.

75 (2001) 66 A.L.D. 25, 39 [60].

76 Mathew, "Human Rights" in Blays, Piotrowicz, and Tsamenyi (eds), Public International Law: An Australian Perspective (O.U.P, 1997), at 291. 
1958 simply refers to persons to whom Australia has protection obligations under the Convention and sets out the procedures for the examination and determination of asylum claims. Individuals cannot invoke rights contained in either the 1951 Convention or 1967 Protocol in domestic proceedings. Nor are obligations arising thereunder, absent transformation into domestic law, binding on the government. ${ }^{77}$ However, the High Court especially has used, in particular, human rights treaties as a tool of interpretation in respect of statutes and as a "legitimate and important influence on the development of the common law." " Such an approach "is one appropriate to the times in which we live" 79 preferable to referring to analogous decisions "written often in a different world for different social conditions". ${ }^{80}$ Indeed, as Nafziger has concluded, the key Anglo-American cases ${ }^{81}$ decided at the turn of the twentieth century, were premised on an acceptance of nativism and racial prejudice. ${ }^{82}$ Furthermore, recent Canadian jurisprudence supports such a methodology:

"Since the Case of Proclamations and the Glorious Revolution the Executive's exercise of power, including it's use of the Prerogative, has been subject to the Rule of Law. It would shock the conscience today if the Executive could rely upon the Prerogative to justify actions or omissions that were illegal or contrary to our international commitments. [. . .] I am well aware that International law and international commitments cannot found a cause of action under domestic law unless they have been written into domestic law. I am also aware that, by Statute, Parliament may legalize that which might otherwise be illegal under international law or contrary to our international commitments. [. . .] International law and our international commitments are the metwand against which the legitimacy of the purported use of the Prerogative might be measured by the court." 83

Hence Black C.J.'s approach to the construction of statute and prerogative powers appears defensible. There is no logical reason why an analysis of statutory provisions, as a source of public power, can involve recourse to international treaties but an analysis of the nature of prerogative powers cannot. Similarly, the source of public powers has been discarded by the courts as a controlling factor vis-à-vis amenability to judicial review for some time. ${ }^{84}$

77 Simsek v MacPhee (1982) 148 C.L.R. 636, at 641-2.

78 Mabo v The State of Queensland (No.2) (1992) 175 C.L.R. 1, at 42.

79 Kirby, "The Role of International Standards in Australian Courts" in Alston and Chiam, Treaty Making and Australia (Federation Press, 1995), at 92.

$80 \mathrm{Ibid}$, at 86.

81 Such as Musgrove v Toy [1891] AC 272; The Chinese Exclusion Case 130 U.S. 581 (1889).

82 Nafziger, supra $n$ 55, at 824.

83 Per Wright J. in Aleksic v Canada (Attorney General) [2002] A.C.W.S.J. 4507; 115 A.C.W.S. (3d) 252, at para 11-14.

84 Council for the Civil Service Unions v Minister for the Civil Service [1985] A.C. 374, 407 (per Lord Scarman ). 
The existence of a common law right to deport and exclude aliens has curried judicial favour. ${ }^{85}$ However, in Schmidt v Secretary of State for Home Department, Lord Denning observed: "The common law has now been overtaken by the Aliens Acts and the Orders thereunder." ${ }^{\prime 6}$ The implication is, ostensibly, that the prerogative power was in a state of abeyance. This analysis received endorsement in $R$ v IAT ex parte Secretary of State for the Home Department. ${ }^{87}$ Stuart-Smith LJ opined that: "The Act as a whole abrogates the prerogative power, save to the limited extent provided [by s. 33(5)]." " Jackson has argued that although read literally section 33(5) "could be used to bypass both Act and immigration rules in respect of aliens ... it seems to have been common ground that the effect of the statutory provision was to make actions taken other than under the rules the exercise of the prerogative." ${ }^{\circ 9}$ Thus, prerogative powers expressly preserved in the 1971 Act were not to be relied on to circumvent the comprehensive legislative scheme. Those powers were only to provide a lawful basis for the (favourable) exercise of discretion outside of the legislative scheme; to supplement and not supplant the Act. The 1958 Migration Act contained no such 'saving' provision at the time of the Tampa incident, only retrospectively, via an amendment..$^{90}$

\section{CONCLUSIONS}

\section{(1) The existence and scope of the power claimed}

The Australian government claimed an uncertain prerogative-based power because it was highly convenient for them to do so. It meant they could circumvent the procedural safeguards that the asylum seekers were entitled to under the terms of the Migration Act 1958 and prevent them lodging claims for refugee status. The Federal Court (and High Court) permitted political expediency to trump legal certainty and procedural fairness, thereby undermining the protection of refugees rooted in international law. ${ }^{91}$ The weight of academic authority conflicts with the conclusion reached by the majority in the Federal Court, regarding the existence and scope of the power asserted at common law. Judicial opinions proved, at best, inconclusive on the matter. The interpretation placed upon section 61 of the Constitution by French J. was unsupported. It is striking that the Australian Parliament deemed it necessary to pass the Border Protection (Validation and Enforcement Powers) Act on 26 September 2001 to validate the action taken against the refugees aboard the $M V$ Tampa retrospectively. ${ }^{92}$

85 Schmidt v Secretary of State for Home Department [1969] 2 Ch. 149, at 168, 172. This view was affirmed in $R$ v Governor of Pentonville Prison ex parte Azam [1973] 2 W.L.R. 949, at 960.

86 Ibid, at 168 .

87 [1990] 3 All E.R. 652, at 661.

$88 \mathrm{Ibid}$, at 657 . See also $R \mathrm{v}$ Secretary of State for the Home Department ex parte Samya and ors [1989] Imm. A.R. 75, at 82.

89 Jackson, Immigration Law and Practice (Sweet and Maxwell, 1999), at 723.

90 Border Protection (Validation and Enforcement Powers) Act 2001.

91 See generally Mathew, "Australian Refugee Protection in the Wake of the Tampa" supra $n 7$.

92 S 7A confirms the power claimed by the executive to act outside of the statutory framework: "The existence of statutory powers under this Act does not prevent the 


\section{(2) The relationship between statute and prerogative}

It is hoped that the navigational aids referred to by Black C.J. will be adopted in suitable cases in the future, where judges are required to address the puzzling relationship between statute and prerogative. To reiterate; when determining whether prerogative powers have been displaced by statute, by implication, the following factors are relevant: (1) The importance of the power claimed to the functioning of executive government, but with the caveat that the power must be clearly established and well-used; (2) Whether the area of law had been the preserve of Parliament for a very long time; and (3) International legal obligations (where relevant) carry some weight. One must view the imprecision in some of these terms in the light of the hazy subject matter they seek to direct. The terms do not determine the precise course judges should steer, rather, they are indicators that will see them heading in the right direction.

\section{(3) Legal limbo}

\section{In $T$ v United Kingdom Lord Mustill stated:}

"Neither under international nor English municipal law does a fugitive have any direct right to insist on being received by a country of refuge. [. . .] The [domestic] legislation must be viewed against the background of a complete absence of any common law right, either national or international, for a refugee to insist on being admitted to a foreign country." 93

Herein lies the rub. The asylum seekers aboard the MV Tampa existed in a legal twilight zone. They had no common law right to enter, but, equally, the Australian Government had no lawful means to deport them given the statutory framework extant at the time the Tampa was in its territorial waters. Dauvergne has opined that the absence of a right to enter a state under international law is vital. "While states would breach the Convention by expelling refugees to places where they would be in danger, they are acting well within their 'rights' when they force boats carrying potential refugees away from their shores." 94 Insofar as interdiction beyond territorial waters is concerned, the author's view has received judicial endorsement in European Roma Rights Centre v Immigration Officer at Prague Airport. ${ }^{95}$ The farther

exercise of any executive power of the Commonwealth to protect Australia's borders. ..". Thus, it is comparable to s 33(5) of the 1971 Immigration Act. For a critical analysis of the changes made to asylum law in the aftermath of the Tampa incident, see Mathew, ibid, Crock, and Saul, Future Seekers: Refugees and the Law in Australia (Federation Press, 2002), at chap 7, and Edwards, "Tampering with Refugee Protection: The Case of Australia” (2003) 15(2) IJRL 192.

93 [1996] A.C. 742, at 754, 758.

94 Dauvergne, "The Dilemma of Rights Discourse for Refugees" (2000) 23(2) UNSWLJ 56, 60.

95 [2003] E.W.C.A. Civ 666. The legality of immigration rules applied extraterritorially were questioned, but the court held they were not in violation of the UK's obligations under Art 33. Nor could Art 33 be interpreted to afford putative refugees a right of access to another country. The decision parallels Sale v Haitian Centers Council except the court drew a line between preventing the arrival of asylum seekers (lawful) and returning them to their own country (unlawful) (at [43]). 
away asylum seekers are from surrogate states, the less likely it is that international law will bite. However, where expulsion from territorial waters is concerned the matter is, or ought to have been, transformed. Where, through legislation, states have freely undertaken to respect international legal obligations, their freedom to act can be fettered by the terms of that legislation. ${ }^{96}$ That is, as long as those international obligations remain enshrined (if not incorporated) in the national legal system. Ultimately, Dauvergne's analysis is correct. A state may take the political decision to undermine or renege upon its international treaty obligations and amend or repeal municipal law accordingly.

\section{(4) Threat to democracy and refugee protection}

In 1893 Brewer J, in Fong Yue Ting v US, warned, "The doctrine of powers inherent in sovereignty is one both indefinite and dangerous. . .". 97 Bradley cautioned against the dangers of judicial recognition of a hitherto uncertain power after the ex parte Northumbria Police Authority judgment. Again, in Ruddock axiomatic principles that underpin all liberal constitutions, the rule of law and separation of powers, appear overlooked. Not only is legal certainty compromised, the recognition of the power claimed by the Executive bucks the trend of subjecting prerogative powers to the will of the democratically elected legislature..$^{98}$ The nebulous executive power, given judicial recognition in the Tampa case, may be deployed readily against others when the will of the legislature no longer serves the needs of the government, and it is considered convenient to do so. This concern is far from fanciful given the political climate prevailing in the UK and many other Commonwealth states post September $112001 .{ }^{99}$ For example, in Refugee Council of New Zealand Inc v Attorney-General (No 1) the High Court stated that, "The need for any state to protect its borders, and the central importance of the prerogative power in doing so, is brought into stark relief by the events of September 11."100

The acid test of a liberal democracy is how it treats 'the other', especially in testing times. In response to rising numbers of asylum claimants, whom

96 See $R$ v Secretary of State for Home Department ex parte JCWI [1996] 4 All E.R. 385 , at 401-2, where the right of access to the asylum determination system was implied from the terms of the Asylum and Immigration Appeals Act 1993. In $T$ v UK, supra n 93, at 754(b), it was observed that: "Subject only to qualifications created by statute this country is entirely free to decide as a matter of executive discretion, which foreigners it allows to remain within its boundaries."

97149 U.S. 698, 737 (1893).

98 Ex parte Fire Brigades Union [1995] 2 AC 513, at 552.

99 Ministers sought to justify the Government's response to the Tampa refugees as the Federal Court deliberated with reference to the link between the arrival of refugees on boats and terrorists. See Head, supra n 2, at 30; Crock and Saul supra n 92, at 38. On the 9/11 phenomenon see Thomas, "September $11^{\text {th }}$ and Good Governance (2002) 53 NILQ 366.

100 [2002] N.Z.A.R. 717 [23]. The case dealt with the legality of detaining all asylum seekers (including some who had been aboard the MV Tampa) under the Immigration Act $1987 \mathrm{~s} 128$. The court determined that at common law and under international law, New Zealand had the right to regulate admission to its territory. 
Western governments perceive to be vexatious generally, ${ }^{101}$ states have employed policies of external deterrence. These policies are blunt instruments affecting all migrants, including genuine asylum seekers, indiscriminately. This fact has been recognised at both political ${ }^{102}$ and judicial levels in the UK:

"The problems facing refugees in their quest for asylum need little emphasis. Prominent amongst them is the difficulty of gaining access to a friendly shore. [. . .] Although under the Convention subscribing states must give sanctuary to any refugee who seeks asylum (subject only to removal to a safe third country), they are by no means bound to facilitate his arrival. Rather they strive increasingly to prevent it."103

Interdiction is but one of a number of strategies employed by Western states to reduce the increasing numbers of asylum seekers arriving. Additionally, states have imposed visa restrictions on countries generating asylum seekers and financial sanctions on those carriers bringing migrants into their territory, where those migrants lack the requisite entry documentation. ${ }^{104}$ They have also placed immigration and liaison officers at ports overseas to prevent putative refugees from reaching their intended sanctuary. ${ }^{105}$ Collectively, these strategies empty the right to seek asylum of its legal, if not moral, value. Moreover, they insulate states from their commitments under the Geneva Convention and its Protocol, and other international human rights treaties.

The decision in Ruddock gives cause for serious concern at an international and domestic level. Firstly, regarding international refugee protection, the decision operates as another reminder of the increasingly common practice of states of barring access to determination procedures. The gulf between state practice and international treaty norms demonstrates that Western refugee-receiving states pay lip service to the right to seek asylum and international human rights standards. The practice of interdiction at sea is indicative of how states are guarding their legal sovereignty in the field of immigration and asylum robustly. Where their interests and policies conflict with international human rights law, national courts have permitted the

101 For an analysis of the deconstruction of refugees by politicians and the media, see Billings, "Alienating Asylum Seekers: Welfare Support in the Immigration and Asylum Act 1999" (2002) 9(3) JSSL 115, 116-124.

102 Home Affairs Committee (May 12, 1998) per Mike O'Brien (then Immigration Minister).

103 See $R$ v Uxbridge Magistrates' Court ex parte Adimi [2001] Q.B. 667 at 673-74 per Simon Brown L.J..

104 See generally, Billings, "A Comparative Analysis of Administrative and Adjudicative Systems for Determining Asylum Claims" (2000) 52(1) Admin LR 253, and Legomsky, "An Asylum Seeker's Bill of Rights in a Non-Utopian World" (2000) 14 Geo Immigr LJ 619. Both papers analyse internal and external strategies for managing the increasing volume of asylum claims utilised in recent years.

105 For example, the pre-clearance entry controls were introduced at Prague's Ruzyne airport on July 18 2001, pursuant to Art 7(1) Immigration (Leave to Enter and Remain) Order 2000. See European Roma Rights Centre, supra n 95. 
former to trump the latter. ${ }^{106}$ Indeed, the case functions as a microcosm of the edifice upon which refugee protection is built. The 1951 Convention represented "a compromise between the exclusive power of the state over entry into and presence in its territory, the very essence of sovereignty, and the competing humanitarian impulse to aid strangers in necessitous circumstances."107 On the one hand, states yielded their absolute control over immigration by agreeing upon formal legal criteria for defining a refugee. On the other, relinquishing total control over the admittance of non-nationals, by permitting international law to encroach into, arguably, the most jealously guarded area of state sovereignty came at a price; notably, the lack of procedural specification in the Convention or Protocol. ${ }^{108}$ Increasingly, controlling the administrative process of determination does not counterbalance the erosion of state sovereignty that states perceive the Convention to constitute. Consequently, drastic measures, such as interdiction, have been pursued in order to appease public opinion in some host states. Moreover, the willingness of states to undermine applicable human rights standards may encourage and facilitate coordinated regional responses along similar lines. For coastal states in southern Europe the attraction of a formalised EU agreement on interdiction at sea, is self-evident. ${ }^{109}$ Indeed, the European Commission is set to draw up a formal proposal for the launch of the Border Management Agency, possibly in 2004. The agency would coordinate monitoring of land, air and sea borders, especially in the Mediterranean. ${ }^{110}$

Second, the constitutional implications are profound. The majority in Ruddock approved archaic and poorly reasoned precedents to support its determination. Precedents that were established when the prevailing ideology was restrictive nationalism and 'classical immigration law' was the

106 This is generally the case in respect of external policies of deterrence such as interdiction, visa requirements and the use of immigration officials overseas. However, domestic courts have frequently protected the interests of asylum seekers once inside the territory of a host state in the face of internal policies that seek to limit procedural guarantees and the availability of welfare benefits for example.

107 Fitzpatrick, "Flight From Asylum: Trends Toward Temporary Refuge and Local Responses to Forced Migrations" (1994) 35 V'bilt JIL 13, 13-14. Also, see Hathaway, "A Reconsideration of the Underlying Premise of Refugee Law" (1990) 31 Harv Int'l LJ 129, 133.

108 Another reason is that international law generally leaves states free to determine the manner in which they meet their international obligations. However if a state fails to fulfil its international obligations adequately then that state's position in international law becomes affected and may lead to the charge that it is in breach of international law. See generally, Jennings and Watts, Oppenheim's International Law (Longman, 1997), at 82-86.

109 Indeed, the Italians already interdict Albanian migrants in the Adriatic Sea, and British and Spanish naval vessels patrol the Straits of Gibraltar. A common policy on interdiction may be conceived as part of the comprehensive policy of deflection of unwanted migrants away from a border-free Europe. (See generally, Noll, Negotiating Asylum. The EU Acquis, Extraterritorial Protection and the Common Market of Deflection (Martinus Nijhoff, 2000).

110 "EU leaders back creation of border agency in immigration clampdown", Agence France Press (October 16, 2003). 
legal epiphenomenon of the times. ${ }^{111}$ The decision serves to undermine legal certainty, an essential element of the rule of law. Furthermore, the majority's construction of the relationship between statute and executive power was regressive, indulging the Executive's claim without a judicious examination of its merits or the relevance of international law. The Executive's argument, essentially based on communal self-determination, underpinned by concerns about preserving and protecting national identity, culture, and social welfare provision in the face of rising numbers of asylum claims, was legitimate. However, the appropriate forum to air such concerns was Parliament. The fact that the legislature's approval of the interdiction of the Tampa was, subsequently, forthcoming, does not disguise the fact that the Australian Parliament was by-passed over an issue that had been its preserve for a long time.

In this episode, the Australian government retreated into the safe harbour of sovereignty whilst leaving asylum seekers at sea. The Federal Court lowered the veil of obscurity that shrouds the use of such residual discretionary and arbitrary powers further, by virtue of their deference to the Executive. Insulating Australia from refugees in its territorial waters by reliance on the weapon of primitive prerogative powers was wrong legally, and the policy behind it unethical.

111 Schuck, "The Transformation of Immigration Law" (1984) 84(1) Columbia LR 1, 3. 